\title{
ANTIMICROBIAL ANALYSIS OF DIFFERENT PARTS EXTRACT IN DIFFERENT SOLVENT SYSTEM OF A WASTE WEED- CALOTROPIS PROCERA
}

\author{
DATTATREYA KAR ${ }^{1}$, PRATAP KESHARI PATTNAIK ${ }^{2}$, BIBHUDUTTA PATTNAIK ${ }^{1}$, ANANYA KUANAR ${ }^{1 *}$ \\ ${ }^{1}$ Centre of Biotechnology, Siksha 0 Anusandhan University, Kalinga Nagar, Ghatikia, Bhubaneswar - 751 003, Odisha, India. \\ ${ }^{2}$ Department of Microbiology, College of Basic Science and Humanities, Orissa University of Agriculture and Technology, Surya Nagar, \\ Bhubaneswar - 751 003, Odisha, India. Email: ananyakuanar@gmail.com
}

Received: 03 July 2017, Revised and Accepted: 13 November 2017

ABSTRACT

Objective: In the current study, we have focused on the major secondary metabolite containing parts such as flower, leaf, and root for phytochemical extraction with three different solvent systems to make a comparative study against three virulent bacteria species which are capable of intestinal infection, pneumonia, skin infections, and food poisoning.

Methods: Antimicrobial activity of ethanol, methanol, and chloroform extracts from bark, leaves and roots of Calotropis procera, was examined against three virulent bacteria species: Escherichia coli, Staphylococcus aureus, and Bacillus subtilis using disc diffusion method.

Results: The ethanol extract of leaf showed significant activity against $S$. aureus with a zone of inhibition ranging from 14 to 20 mm for $S$. aureus. The ethanol extract of flower was effective against E. coli with maximum $18 \mathrm{~mm}$. Ethanol extract of root showed significant activity against $S$. aureus. Methanol extract of leaves showed moderate activity against $S$. aureus with a zone of inhibition ranging from 14 to 20 mm. Methanol extract of root showed significant activity against $S$. aureus with a zone of inhibition ranging from 12 to $22 \mathrm{~mm}$. Methanol extract of flowers showed activity against E. coli with a zone of inhibition ranging from 11 to $20 \mathrm{~mm}$. The chloroform extract of leaves showed significant activity against $S$. aureus. Chloroform extract of flower showed activity with zone of inhibition ranging from 11 to $17 \mathrm{~mm}$ for S. aureus chloroform extract of root showed activity against E. coli with zone of inhibition ranging from 9 to $17 \mathrm{~mm}$.

Conclusion: From the above study, it can be concluded that the activity of the plant extract may be due to the secondary metabolites or broadspectrum antibiotic compounds present in it.

Keywords: Calotropis procera, Antimicrobial, Weeds.

(c) 2018 The Authors. Published by Innovare Academic Sciences Pvt Ltd. This is an open access article under the CC BY license (http://creativecommons. org/licenses/by/4. 0/) DOI: http://dx.doi.org/10.22159/ajpcr.2018.v11i2.21081

\section{INTRODUCTION}

"Weeds" are the valueless plant that grows wildly. A plant is named to be weed when it is found abundantly or due to lack of knowledge about its significant value. But being a plant biologist baptizing a plant with such terms is a matter of regret. Now it is a challenge for every researcher to acknowledge human society with the significant value of every individual plant. Day-by-day trees are getting poached for urbanization and a very limited number of plants are seen in urban areas. In such places, the weeds are the only source of green view due to nature's green view, act as vision therapy for eyes. There are some weeds used for human consumption [1] and cattle fodders. Weeds have high pharmaceutical values [2] such as Tridax procumbens have antimicrobial [3,4], antiseptic, insecticidal, parasiticidal [5], and anticancerous activity [6] as its rich in secondary metabolites.

Calotropis procera or milk weed (high latex content) belongs to the family of Apocynaceae are consider as a common weed in many parts of the world. Its vegetation is widely seen in Indochina, south Asia, west Asia, North, and Tropical region of Africa. Being a weed this plant has a high significant value such as its parts such as leaf, flower, stem, and roots has been used for the treatment of common diseases such as antibacterial [7] antifungal [8], antipyretic [9], and analgesic problem [10]. Scientific reports suggest that this herb has effective treatment such as paralysis, rheumatic pain [11], expectorant, and antiinflammatory $[12,13]$

In the current study, we have focused on the major secondary metabolite containing parts such as flower, leaf, and root for phytochemical extraction with three different solvent systems (ethanol, methanol, and chloroform) to make a comparative study against three virulent bacteria species (Escherichia coli, Staphylococcus aureus, and Bacilus subtilis) which are capable of intestinal infection, pneumonia, skin infections, and food poisoning. The reports available on the antimicrobial study of $C$. procera suggests that no such comparative reports of plant parts, especially the flower has not been reported yet. In the current article, we aim to find the best effective plant part and the solvent system against these pathogenic microbes.

\section{METHODS}

\section{Plant materials}

The plant materials of $C$. procera were collected from Bhubaneswar locality Ghatikia area behind SUM Hospital. A fresh sample of the plant was identified by professor Baldev Khuntia Ex-reader Botany, College of Basic Science and Humanity, OUAT, Bhubaneswar.

\section{Pre-processing of plant materials}

The plant parts were washed thoroughly under running tap water and rewashed with distilled water then the plant parts were separated and cut into small pieces which were kept in the shade for drying about 15 days. The dry plant parts were collected and were grinded in an electric grinder into fine powder. Each parts powder was collected in a different plastic pouch and clearly labeled and stored for extraction.

\section{Preparation of plant extracts}

The powered extracts of different parts were weighed up to $100 \mathrm{~g}$ and were taken individually in different Soxhlet apparatus (Borosil 
Glasswork Limited, Worli, Mumbai, India) using ethanol as solvent. The temperature of the apparatus was set to $40^{\circ} \mathrm{C}$ for $18-20 \mathrm{~h}$. The extract was collected and filtered through Whatman no. 1 filter paper then the crude extract was concentrated at room temperature. The crude extract was collected and was stored at $4^{\circ} \mathrm{C}$ until the further analysis. The above procedure was repeated for both methanol and chloroform solvent.

\section{Test microorganisms and growth media}

Bacteria strains of E. coli, S. aureus, and B. subtilis were chosen based on their clinical and pharmacological importance. The bacterial strains obtained from the Department of Microbiology, College of Basic Science and Humanities, OUAT, Bhubaneswar, were used for evaluating antimicrobial activity. The bacterial stock cultures were incubated for $24 \mathrm{~h}$ at $37^{\circ} \mathrm{C}$ on nutrient agar and potato dextrose agar (PDA) medium (HiMedia), respectively, following refrigeration storage at $4^{\circ} \mathrm{C}$. The bacterial strains were grown in Mueller-Hinton agar (MHA) plates at $37^{\circ} \mathrm{C}$ (the bacteria were grown in the nutrient broth at $37^{\circ} \mathrm{C}$ and maintained on nutrient agar slants at $4^{\circ} \mathrm{C}$ ), whereas the fungal strains were grown in Sabouraud dextrose agar and PDA media, respectively, at $28^{\circ} \mathrm{C}$. The stock cultures were maintained at $4^{\circ} \mathrm{C}$.

\section{Antimicrobial test}

Antimicrobial activities of ethanolic, methanolic, and chloroform extracts of $C$. procera were determined by filter paper disc diffusion method.

\section{Disc diffusion method}

Sterile filter disc (diameter $4 \mathrm{~mm}$, Whatman paper No. 3) was placed in Petri dishes (diameter $90 \mathrm{~mm}$ ) filled with MHA and seeded with $0.3 \mathrm{ml}$ of the test organism. The disc was impregnated with test concentrations $(25,50,75$, and $100 \mu \mathrm{g} / \mathrm{ml})$ of the compounds investigated dissolved in dimethyl sulfoxide (DMSO). The zones of growth inhibition around the discs were measured after $24 \mathrm{~h}$ of incubation at $37^{\circ} \mathrm{C}$. Each microorganism was tested in triplicate, and the solvent (DMSO) was used as a control, while streptomycin was used as a positive control.

\section{Minimum inhibitory concentration (MIC)}

Different concentrations of the flower, leaf, and root extracts of C. procera were prepared to obtain $2.5 \mathrm{mg} / \mathrm{ml}, 5.0 \mathrm{mg} / \mathrm{ml}$, and $7.5 \mathrm{mg} / \mathrm{ml}$. Three drops of overnight broth culture of the test organisms were inoculated into the dilutions and incubated at $37^{\circ} \mathrm{C}$ for $24 \mathrm{~h}$. The lowest concentration of the extracts that inhibited the growth of the test organisms was recorded as the MIC.

\section{Statistical analysis}

Results obtained were reported as the mean \pm standard deviation of triplicate measurements. Significance differences for multiple comparisons were determined by one-way analysis of variance followed by Duncan test with $\mathrm{p}=0.05$ using SPSS (version 19).

\section{RESULTS}

The result of antibacterial sensitive of ethanol, methanol, and chloroform extracts of flower, leaves, and root of the plant under study against the three different bacterial strains are interpreted in Tables 1-3.

The ethanol extract of leaf showed significant activity against $S$. aureus and E. coli with a zone of inhibition ranging from 14 to $20 \mathrm{~mm}$ for S. aureus and 10.11 for E. coli. B. subtilis is not resistant, and the zone of inhibition was not seen. The ethanol extract of flower was effective against $E$. coli with maximum $18 \mathrm{~mm}$ at $100 \mu \mathrm{l}(20 \mathrm{mg})$. S. aureus also showed significant zero of inhibition. B. subtilis is not resistant to ethanol extract of root showed significant activity against $S$. aureus and 10-20 mm for E. coli. Zone of inhibition was not seen in B. subtilis.

Methanol extract of leaves showed moderate activity against $S$. aureus with a zone of inhibition ranging from 14 to $20 \mathrm{~mm}(25-100 \mu \mathrm{l})$ and E. coli $12-18 \mathrm{~mm}(25-100 \mu \mathrm{l})$. B. subtilis was not resistance against the extract. Methanol extract of root showed significant activity against $S$. aureus with zone of inhibition ranging from 12 to $22 \mathrm{~mm}(25-100 \mu \mathrm{l})$ and $E$. coli $11-19 \mathrm{~mm}(25-100 \mu \mathrm{l})$. B. subtilis was not resistant against the extract. Methanol extract of flowers showed activity against $E$. coli with a zone of inhibition ranging from 11 to $20 \mathrm{~mm}(25-100 \mu \mathrm{l})$. B. subtilis was not resistant against the extract.

The chloroform extract of leaves showed significant activity against $S$. aureus and E. coli. Chloroform extract of flower showed activity against $S$. aureus and $E$. coli with zone of inhibition ranging from 11 to $17 \mathrm{~mm}$ for $S$. aureus and $10-16 \mathrm{~mm}$ for $E$. coli. Chloroform extract of root showed activity against $E$. coli with zone of inhibition ranging from

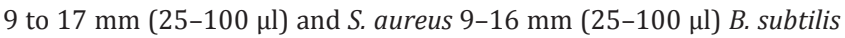
was not resistant against the extract.

The results of MIC are interpreted in Table 4

\section{DISCUSSION}

Drug resistance of human pathogenic bacteria has been reported all over the world, and the situation is alarming in developing as well

Table 1: Antimicrobial activity of different solvent such as ethanol, methanol, and chloroform extracts of $C$. procera (flower)

\begin{tabular}{|c|c|c|c|c|}
\hline \multirow[t]{4}{*}{ Name of the solvent extracts } & \multirow[t]{4}{*}{ Concentration of the extract } & \multicolumn{3}{|c|}{ Diameter of zone of inhibition $(\mathrm{mm} \pm \mathrm{SD})$} \\
\hline & & \multicolumn{3}{|c|}{ Name of the organism } \\
\hline & & \multicolumn{3}{|c|}{ Bacterial species } \\
\hline & & E. coli & S. aureus & B. subtilis \\
\hline DMSO & $\mathrm{NC}$ & - & - & - \\
\hline \multirow[t]{3}{*}{ Ethanol } & $25 \mu \mathrm{l}(5 \mathrm{mg})$ & $09 \pm 0.08$ & $10 \pm 0.08$ & - \\
\hline & $75 \mu \mathrm{l}(15 \mathrm{mg})$ & $16 \pm 0.09$ & $15 \pm 0.08$ & - \\
\hline & $100 \mu \mathrm{l}(20 \mathrm{mg})$ & $18 \pm 0.11$ & $17 \pm 0.05$ & - \\
\hline \multirow[t]{4}{*}{ Methanol } & $25 \mu \mathrm{l}(5 \mathrm{mg})$ & $11 \pm 0.01$ & $09 \pm 0.07$ & - \\
\hline & $50 \mu \mathrm{l}(10 \mathrm{mg})$ & $15 \pm 0.07$ & $11 \pm 0.10$ & - \\
\hline & $75 \mu \mathrm{l}(15 \mathrm{mg})$ & $17 \pm 0.06$ & $14 \pm 0.08$ & - \\
\hline & $100 \mu \mathrm{l}(20 \mathrm{mg})$ & $20 \pm 0.04$ & $19 \pm 0.05$ & - \\
\hline \multirow[t]{3}{*}{ Chloroform } & $25 \mu \mathrm{l}(5 \mathrm{mg})$ & $10 \pm 0.16$ & $11 \pm 0.01$ & - \\
\hline & $50 \mu \mathrm{l}(10 \mathrm{mg})$ & $12 \pm 0.03$ & $13 \pm 0.04$ & - \\
\hline & $100 \mu \mathrm{l}(20 \mathrm{mg})$ & $16 \pm 0.08$ & $17 \pm 0.06$ & - \\
\hline Streptomycin & PC $(10 \mu \mathrm{g})$ & $22 \pm 0.10$ & $20 \pm 0.30$ & $12 \pm 0.20$ \\
\hline
\end{tabular}

Values are expressed as mean zone of inhibition (mm) \pm SD of three replicate. NC: Negative control, PC: Possitive control (streptomycsin), -: No activity, C. procera: Calotropis procera, E. coli: Escherichia coli, S. aureus: Staphylococcus aureus, B. subtilis: Bacillus subtilis, SD: Standard deviation, DMSO: Dimethyl sulfoxide 
Table 2: Antimicrobial activity of different solvents such as ethanol, methanol, and chloroform extracts of $C$. procera (Leaf)

\begin{tabular}{|c|c|c|c|c|}
\hline \multirow[t]{4}{*}{ Name of the solvent extracts } & \multirow[t]{4}{*}{ Concentration of the extract } & \multicolumn{3}{|c|}{ Diameter of zone of inhibition $(\mathrm{mm} \pm \mathrm{SD})$} \\
\hline & & \multicolumn{3}{|c|}{ Name of the organism } \\
\hline & & \multicolumn{3}{|c|}{ Bacterial species } \\
\hline & & E. coli & S. aureus & B. subtilis \\
\hline DMSO & NC & - & - & - \\
\hline \multirow{3}{*}{ Ethanol } & $25 \mu \mathrm{l}(5 \mathrm{mg})$ & $10 \pm 0.08$ & $14 \pm 0.10$ & - \\
\hline & $75 \mu \mathrm{l}(15 \mathrm{mg})$ & $10 \pm 0.08$ & $17 \pm 0.03$ & - \\
\hline & $100 \mu \mathrm{l}(20 \mathrm{mg})$ & $11 \pm 0.15$ & $20 \pm 0.12$ & - \\
\hline \multirow[t]{4}{*}{ Methanol } & $25 \mu \mathrm{l}(5 \mathrm{mg})$ & $12 \pm 0.06$ & $14 \pm 0.10$ & - \\
\hline & $50 \mu \mathrm{l}(10 \mathrm{mg})$ & $14 \pm 0.02$ & $16 \pm 0.05$ & - \\
\hline & $75 \mu \mathrm{l}(15 \mathrm{mg})$ & $16 \pm 0.20$ & $19 \pm 0.07$ & - \\
\hline & $100 \mu \mathrm{l}(20 \mathrm{mg})$ & $18 \pm 0.10$ & $20 \pm 0.21$ & - \\
\hline \multirow[t]{2}{*}{ Chloroform } & $25 \mu \mathrm{l}(5 \mathrm{mg})$ & $08 \pm 0.01$ & $09 \pm 0.02$ & - \\
\hline & $50 \mu \mathrm{l}(10 \mathrm{mg})$ & $09 \pm 0.02$ & $12 \pm 0.12$ & - \\
\hline Streptomycin & PC $(10 \mu \mathrm{g})$ & $20 \pm 0.10$ & $22 \pm 0.10$ & $12 \pm 0.02$ \\
\hline
\end{tabular}

Values are expressed as mean zone of inhibition (mm) \pm SD of three replicate. NC: Negative control, PC: Positsive control (stresptomycin), -: No activity,

C. procera: Calotropis procera, E. coli: Escherichia coli, S. aureus: Staphylococcus aureus, B. subtilis: Bacillus subtilis, SD: Standard deviation, DMSO: Dimethyl sulfoxide

Table 3: Antimicrobial activity of different solvents such as ethanol, methanol, and chloroform extracts of C. procera (root)

\begin{tabular}{|c|c|c|c|c|}
\hline \multirow[t]{4}{*}{ Name of the solvent extracts } & \multirow[t]{4}{*}{ Concentration of the extract } & \multicolumn{3}{|c|}{ Diameter of zone of inhibition $(\mathrm{mm} \pm \mathrm{SD})$} \\
\hline & & \multicolumn{3}{|c|}{ Name of the organism } \\
\hline & & \multicolumn{3}{|c|}{ Bacterial species } \\
\hline & & E. coli & S. aureus & B. subtilis \\
\hline DMSO & $\mathrm{NC}$ & - & - & - \\
\hline \multirow[t]{3}{*}{ Ethanol } & $25 \mu \mathrm{l}(5 \mathrm{mg})$ & $10 \pm 0.02$ & $10 \pm 0.09$ & - \\
\hline & $75 \mu \mathrm{l}(15 \mathrm{mg})$ & $15 \pm 0.06$ & $18 \pm 0.03$ & - \\
\hline & $100 \mu \mathrm{l}(20 \mathrm{mg})$ & $20 \pm 0.05$ & $21 \pm 0.04$ & - \\
\hline \multirow[t]{4}{*}{ Methanol } & $25 \mu \mathrm{l}(5 \mathrm{mg})$ & $11 \pm 0.03$ & $12 \pm 0.10$ & - \\
\hline & $50 \mu \mathrm{l}(10 \mathrm{mg})$ & $12 \pm 0.06$ & $14 \pm 0.04$ & - \\
\hline & $75 \mu \mathrm{l}(15 \mathrm{mg})$ & $15 \pm 0.07$ & $18 \pm 0.09$ & - \\
\hline & $100 \mu \mathrm{l}(20 \mathrm{mg})$ & $19 \pm 0.05$ & $22 \pm 0.06$ & - \\
\hline \multirow[t]{3}{*}{ Chloroform } & $25 \mu \mathrm{l}(5 \mathrm{mg})$ & $09 \pm 0.02$ & $09 \pm 0.06$ & - \\
\hline & $50 \mu \mathrm{l}(10 \mathrm{mg})$ & $10 \pm 0.07$ & $10 \pm 0.05$ & - \\
\hline & $100 \mu \mathrm{l}(20 \mathrm{mg})$ & $17 \pm 0.10$ & $16 \pm 0.07$ & - \\
\hline Streptomycin & PC $(10 \mu \mathrm{g})$ & $22 \pm 0.30$ & $24 \pm 0.10$ & $12 \pm 0.30$ \\
\hline
\end{tabular}

Values are expressed as mean zone of inhibition (mm) \pm SD of three replicate. NC: Negative control, PC: Positive control (streptomycin), -: No activity,

C. procera: Calotropis procera, E. coli: Escherichia coli, S. aureus: Staphylococcus aureus, B. subtilis: Bacillus subtilis, SD: Standard deviation, DMSO: Dimethyl sulfoxide

Table 4: Minimum inhibitory concentration $(\mathrm{mg} / \mathrm{ml})$ of different parts of Calotropis procera

\begin{tabular}{llll}
\hline Test organisms & $\begin{array}{l}\text { Ethanolic leaf extracts of } \\
\text { Calotropis procera }(\mathbf{m g} / \mathbf{m l})\end{array}$ & $\begin{array}{l}\text { Ethanolic root extracts of } \\
\text { Calotropis procera } \mathbf{( m g} / \mathbf{m l})\end{array}$ & $\begin{array}{l}\text { Ethanolic flower extracts of } \\
\text { Calotropis procera }(\mathbf{m g} / \mathbf{m l})\end{array}$ \\
\hline Bacteria & 5.0 & 5.0 & 5.0 \\
\hline E. coli & - & - & - \\
B. subtilis & 5.0 & 5.0 & 5.0 \\
S. aureus & . & & \\
\hline
\end{tabular}

E. coli: Escherichia coli, S. aureus: Staphylococcus aureus, B. subtilis: Bacillus subtilis

as developed countries due to in the discriminate use of antibiotics. Plants are an important source of potentially useful structures for the development of novel chemotherapeutic agents and the first step toward this goal is the in vitro antibacterial assay [14].

An antimicrobial is a substance that kills or inhibits the growth of microorganisms such bacteria, fungi, or protozoan. Antimicrobial agents either kill microbes (microbiocidal) or prevent the growth of microbes (microbiostatic). Various parts of medicinal plants such as the leaves, flowers, fruits, roots and the bark extract, infusion, decorations, and powders have proven useful in curing a wide range of healthrelated issues [15]. The present study was conducted to analyze the antibacterial activity of $C$. procera with optimized conditions.

Further work was only carried out the used parts of samples $C$. procera were leaves root and flowers with three solvents, i.e. methanol, ethanol, and chloroform. A weak antibacterial property of ethanolic extracts of $C$ procera leaves and latex against E. coli, S. aureus, Salmonella sp., and Pseudomonas species was recorded using paper-disc diffusion and broth dilution techniques. The results obtained revealed that ethanol 
was the best extractive solvent for a fraction with antibacterial activity. Furthermore, ethanol was reported for its efficiency for extracting the antimicrobial active substances from calotropis compared to other solvents [16]. The used solvent is an important factor for the isolation of selective bioactive compounds [17]. In our results, methanol extracts of leaves exhibited much more bioactivity than other extracts. This is close agreement with Manilal et al. 2009, Rangaiah et al. 2010 [18,19].

Pandey et al. [20] also reported the maximum zone of inhibition was recorded in case of leaves of methanol extract of $C$. procera against E. coli ranging $25.5 \mathrm{~mm}$ of zone of inhibition. Ranjit et al. [21] reported flowers of $C$. procera shows antibacterial action against Gram-positive and Gram-negative microorganism. Some other reports are also reported that various parts of this plant show that antimicrobial activities $[8,16,22,23]$. Some other reports are also reported that various part of this genera shows that antimicrobial activity [24].

In the present study, both ethanol and methanol extracts were effective against some bacterial strains. Methanol extract was more effective against the bacteria compared to ethanol extract. The extracts were not effective against $B$. subtilis. From the above study, it can be concluded that the activity of the plant extract may be due to the secondary metabolites or broad-spectrum antibiotic compounds present in it. The polarity of the solvent seems to play an important role in exhibiting potential antibacterial activity [25].

\section{CONCLUSION}

As the searches for new drugs are in demand, plant extracts may provide an attractive alternative source against various infections and chronic disease. Furthermore, due to multidrug-resistant microorganisms and side effects of the synthetic drugs, these studies can be helpful in discovering new therapeutic agents with less or no side effects. It can finally be concluded that weeds are valuable medicines and should be protected. Therefore, there is huge room for research in the direction of more pharmacological activities of plant and to elucidate the mechanism of action of same in future.

\section{ACKNOWLEDGMENTS}

The authors are also grateful to Vice-chancellor, Orissa University of Agriculture and Technology, for providing financial support and encouraging throughout.

\section{CONFLICTS OF INTERESTS}

we declare that we have no conflict of interest

\section{REFERENCES}

1. Maroyi A. Use of weeds as traditional vegetables in Shurugwi district, Zimbabwe. J Ethnobiol Ethnomed 2013;9:60.

2. Stepp JR. The role of weeds as sources of pharmaceuticals. J Ethnopharmacol 2004;92:163-6.

3. Mahato RB, Chaudhary RP. Ethnomedicinal study and bacterial activities of selected plants of Palpa district, Nepal. Sci World 2005;3:26-31.

4. Sharma B, Kumar P. Extraction and pharmacological evaluation of some extracts of Tridax procumbens and Capparis decidua. Int J Appl Res Nat Prod 2009;1:5-12.
5. Saxena VK, Albert S. B-sitosterol-3-O-bD-xylopyranoside from the flowers of Tridax procumbens Linn. J Chem Soc 2005;117:263-6.

6. Priya PV, Radhika K, Sivakumar R, Sri Ramchandra M, Prameela Devi V, Srinivasa R. Evaluation of anticancer activity of T. Procumbens flower extracts on PC3 cell lines. Int J Adv Pharm Sci 2011;2:28-30.

7. Shetty VG, Patil MG, Dound AS. Evaluation of phytochemical and antibacterial properties of Calotropis procera (AIT) R. BR. Leaves. Int J Pharm Pharm Sci 2015;7:316-9.

8. Larhsin M, Bousaid M, Lazrek HB, Jana M, Amarouch H. Evaluation of antifungal and molluscidal properties of extract of Calotropis procera. Fitoterapia 1997;68:371-3.

9. Al-Yahya MA, Al-Meshal IA, Mossa JS, Tariq M. Phytochemical and Pharmacological Studies on Calotropis procera. Lecatecas, Mexico: Proceeding of the $3^{\text {rd }}$ International Conference of traditional and Folk Medicine; 1985.

10. Mohsin A, Shah AH, Alaha MA, Tariqi MO, Ageel AM. Analytic antipyretic activity and phytochemical screening of some plants used in traditional Arab systems of medicine. Fitoterapia 1989;60:174-7.

11. Sebastian MK, Bhandari MM. Medico-ethno botany of mount abu, Rajasthan, India. J Ethnopharmacol 1984;12:223-30.

12. Kapur SK, Sarin YK. Medico-botanical survey of medicinal and aromatic plants of Katra valley (J.K. State), India. Indian Drugs 1984;22:4-10.

13. Sureshbabu AR, Karki SS. Anti-inflammatory activity of various extracts of roots of Calotropis procera against different inflammation models. Int J Pharm Pharm Sci 2011;3:191-4.

14. Valero M, Salmerón MC. Antibacterial activity of 11 essential oils against Bacillus cereus in tyndallized carrot broth. Int J Food Microbiol 2003;85:73-81

15. Prabha M, Vasantha K. Phytochemical and antibacterial activity of Calotropis procera (Ait.) R.Br. Flowers. Int J Pharm Biosci 2012;3:1-6.

16. Kareem SO, Akpan I, Ojo OP. Antimicrobial activities of Calotropis procera on selected pathogenic microorganisms. Afr J Biomed Res 2008;11:105-10

17. Salem WM, Galal H, El-deen FN. Screening for antibacterial activities in some marine algae from the red sea (Hurgada, Egypt). Afr J Microbiol Res 2011;5:2160-7.

18. Manilal A, Sujith S, Selvin J, Shakir C, Kiran GS. Antibacterial activity of Falkenbergia hillebrandii (Born) from the Indian coast against human pathogens. Phyton 2009;78:161-6.

19. Rangaiah SG, Lakshmi P, Manjula E. Antimicrobial activity of seaweeds Gracillaria padina and Sargassum sps. On clinical and phytopathogens. Int J Chem Anal Sci 2010;1:114-7.

20. Pandey A, Agrawal S, Bhatia AK, Saxena A. In vitro Assessment of antibacterial activity of Calotropis procera and Coriandrum sativum against various pathogens. Int J Pharm Res Allied Sci 2015;4:33-44.

21. Ranjit PM, Santhipriya T, Nagasri S, Chowdary YA, Gopal PN. Preliminary phytochemical screening and antibacterial activities of ethanolic extract of Calotropis procera flowers against human pathogenic strains. Asian J Pharm Clin Res 2012;5:127-31.

22. Kawo AH, Mustapha A, Abdullahi BA, Rogo LD, Gaiya ZA, Kumurya AS. Phytochemical properties and antibacterial activities of the leaf and latex extracts of Calotropis procera (Ait. F.). Bayero J Pune Appl Sci 2009;2:34-40.

23. Bhaskar VH. Antimicrobial activity of Calotropis procera Seeds. Asian J chem 2000;21:5788-90.

24. Kar D, Kuanar A, Pattanaik PK. Antimicrobial activities of different parts of Calotropis gigantea: A naturally occurring prophylactic medicinal shrub. Iran J Sci Technol Trans Sci 2016. Available from: https://www.doi.org/10.1007/s40995-016-0079-7.

25. Ahirwal L, Singh S, Mehta A. Antimicrobial screening of methanol and aqueous extracts of Swertia chirata. Int $\mathrm{J}$ Pharm Pharm Sci 2011;3:142-6. 